Int. J. Dev. Biol. 61: 357-366 (2017)

doi: $10.1387 / \mathrm{ijdb} .160343 \mathrm{LB}$

\title{
States of $G_{0}$ and the proliferation-quiescence decision in cells, tissues and during development
}

\author{
DAN SUN and LAURA BUTTITTA* \\ Dept. of Molecular, Cellular and Developmental Biology, University of Michigan, Ann Arbor, MI, USA
}

\begin{abstract}
While cellular proliferation is fundamental to the development of all multicellular organisms, the slowing or stopping of proliferation at the right places and times is equally important for proper tissue and organ development. The non-cycling state of cellular quiescence or " $G_{0}$ " is relatively understudied compared to proliferation, given its prevalence in nature. It may seem that actively proliferating cells undergo a series of dynamic events, while quiescent cells are in a passive, static state. However, studies over the last 10-15 years suggest that quiescence may be more dynamic than previously thought and must also be actively regulated and maintained. This review focuses on recent advances in understanding quiescence or $G_{0}$ and in particular, on observations about the proliferation-quiescence decision in cell lines, in tissues and during development. We also discuss novel, advanced molecular tools that are likely to enable the field to address outstanding, unresolved questions about cellular quiescence and its regulation.
\end{abstract}

KEY WORDS: cell cycle arrest, terminal differentiation, restriction point

\section{Quiescence and $G_{0}$}

$\mathrm{G}_{0}$ is a term broadly used to refer to a prolonged cell cycle arrest, or a sustained non-dividing state. $G_{0}$ can encompass distinct states, distinguished by their range of reversibility: from easily reversible to non-reversible (Fig.1). The term reversible quiescence has sometimes been used to describe cells that are not actively cycling, but may re-enter the cell cycle upon external stimuli. Examples include stem cells that respond to signals upon wounding to maintain tissue homeostasis or dormant cancer cells that can suddenly re-enter the cell cycle to seed recurrent tumors. This term also is commonly used to describe cells that are not dividing due to nutrient or growth factor starvation, for example in cell culture. In contrast, cells that acquire their final fate and undergo terminal differentiation during development, often enter a prolonged or sometimes permanent cell cycle arrest, which is also referred to as $G_{0}$. This is a feature characteristic of neurons, mature epithelia and differentiated muscle to name a few examples. In some organisms however, certain mature, differentiated cell types maintain a reversible $G_{0}$ and can re-enter the cell cycle upon damage. This includes examples such as mature muscle from amputated axolotl limbs (Sugiura et al., 2016), the extraocular muscles of zebrafish (Saera-Vila et al., 2015), Müller glia of the zebrafish retina (Wan and Goldman, 2016), and the sensory epithelium of the avian inner ear (Tsue et al., 1994). A third state of cell cycle arrest, senescence, is also often referred to as $G_{0}$. In senescence, cells exit from the cell cycle in response to telomere loss, stress, accumulation of DNA damage or aberrant oncogenic activity, and undergo permanent arrest accompanied by metabolic, nuclear and morphological changes associated with DNA damage (Salama et al., 2014). Senescence often represents a general response to aging and stress (Chandler and Peters, 2013), but recent work has shown that senescence also occurs during normal development (Munoz-Espin et al., 2013, Storer et al., 2013).

While most $G_{0}$ cells are thought to exit the cell cycle in $G_{1}$ phase or with a $G_{1}$ DNA content (2C), not all cells do so. For example, in human epidermis, differentiating keratinocytes undergo additional replication without cell division and finally exit the cell cycle with polyploid DNA (Zanet et al., 2010). Cells in the liver, heart and placenta can be quiescent in $\mathrm{G}_{0}$ with $4 \mathrm{C}, 8 \mathrm{C}$ or greater DNA content (Fox and Duronio, 2013), and in plants, several rounds of endocycling (cell cycles lacking mitosis and consisting of Gap and S-phases only) occur before terminal differentiation in trichome cells, resulting in cell cycle exit with 32C DNA (Orr-Weaver, 2015).

Abbreviations used in this paper: CDK, cyclin-dependent kinase; CKI, cyclin-dependent kinase inhibitor; Rb, retinoblastoma.

\footnotetext{
*Address correspondence to: Laura Buttitta. Dept. of Molecular, Cellular and Developmental Biology, University of Michigan, Ann Arbor, MI 48109, USA.

E-mail: buttitta@umich.edu - (iD) http://orcid.org/0000-0002-5064-0650
} 
Furthermore, cells that normally exit the cell cycle with a $G_{1}$ DNA content, in many cases can be induced to exit the cell cycle in $G_{2}$. For example, mammalian cells lacking all three of the Retinoblastoma family pocket proteins respond to serum deprivation with massive apoptosis and a prolonged cell cycle arrest in $\mathrm{G}_{2}$, and tissues in Drosophila that normally exit the cell cycle with a $G_{1}$ DNA content can be induced to exit the cell cycle permanently with partially replicated DNA or in $G_{2}$ by genetic manipulations of certain cell cycle regulators (Buttitta et al., 2007, Foijer et al., 2005). Altogether, these observations raise a big question regarding how we diagram and discuss the $G_{0}$ state and cell cycle exit (Fig. 1). If cells do not necessarily leave the cell cycle from $G_{1}$, is this still considered $G_{0}$ ? Or are non-dividing cells with hyperploid DNA in a distinct state from $\mathrm{G}_{0}$ ? This question may also apply to the $\mathrm{G}_{0}$ associated with senescence, as recent work suggests mitotic slippage occurs prior to senescence and many senescent cells in fact do not exhibit a 2C DNA content (Dikovskaya et al., 2015, Restall et al., 2015).

\section{Potential molecular markers of quiescence}

Molecular markers that can distinguish $G_{0}$ cells from cycling $G_{1}$ cells are of great interest in the cell cycle field. Most cell cycle assays such as immunostaining for markers of proliferating cells or flow cytometry cannot distinguish $G_{0}$ from early $G_{1}$ cells since both $\mathrm{G}_{0}$ and $\mathrm{G}_{1}$ cells generally contain a $2 \mathrm{C}$ DNA content, and there may not be any obvious change in cell morphology or size (Pozarowski and Darzynkiewicz, 2004, Zambon, 2010). In some cell types such as skeletal muscle, neurons or keratinocytes, specific molecular markers can be correlated with $\mathrm{G}_{0}$, but these often don't translate to other cell types. Without a universal marker for $\mathrm{G}_{0}$, it has been very challenging to reliably identify $\mathrm{G}_{0}$ cells both in vitro and in vivo. Below is a discussion of existing molecular approaches used to distinguish $\mathrm{G}_{0}$ from $\mathrm{G}_{1}$ cells.

\section{Cyclin-dependent kinase inhibitors as markers of $G_{0}$}

Cell cycle progression is controlled by oscillations of the activity of different cyclin/Cyclin-dependent kinase complexes. The active kinases and the activation process are conversely suppressed by the binding of cyclin-dependent kinase inhibitors (CKIs). The CKI members of the Cip/Kip family (p2 $1^{\mathrm{Cip} 1}, \mathrm{p} 27^{\mathrm{Kip} 1}, \mathrm{p} 57^{\mathrm{Kip} 2}$ ), share a homologous inhibitory domain, which is responsible for the inhibition of the $\mathrm{G}_{1}$ cyclin complexes containing Cdk4 and Cdk2, by direct binding. The Cip/Kip family acts on Cdk2 preferentially in vivo, though they can target all $\mathrm{G}_{1}$ cyclin complexes in vitro (Ortega et al., 2002, Parry et al., 1999, Soos et al., 1996). Disruption of $227^{\text {Kip1 }}$ in mice leads to multiorgan hyperplasia and an increase in the fraction of $S$ phase cells in the thymus, demonstrating that $27^{\text {Kip } 1}$ functions as a negative regulator of cell proliferation in specific contexts during development (Fero et al., 1996, Kiyokawa et al., 1996). Similarly, loss of p57 Kip2 leads to a partial loss of quiescence in the neural stem cells of the hippocampus, and delayed cell cycle exit of terminally differentiating lens cells of the eye and chrondrocytes in limbs (Furutachi et al., 2013, Yan et al., 1997, Zhang et al., 1997). Although mice lacking p21 $1^{\text {Cip } 1}$ exhibit normal tissue development, they display defects in quiescence of hematopoietic stem cells and mouse embryonic fibroblasts (MEFs) lacking p21 exhibit defects in cell cycle arrest in response to DNA damage (Cheng et al., 2000, Deng et al., 1995). Consistent with the tissue specific differences observed in the mutant mice, the Cip/Kip family members exhibit tissue specific expression and can act redundantly to limit proliferation in many cases (reviewed in Pateras et al., 2009).

The CKIs p21 ${ }^{\text {Cip } 1}$ and p27 $7^{\text {Kip } 1}$ are highly expressed during $G_{0}$ (Coller et al., 2006, Oki et al., 2014), but p21 cip1 also transiently accumulates in the nucleus at the G2/M boundary to inhibit CycA/ Cdk2 complexes in response to DNA damage (Dulic et al., 1998). The levels of $\mathrm{p} 27^{\mathrm{Kip} 1}$ may therefore be a useful and specific marker for $G_{0}$. The highest levels of $p 27^{\mathrm{Kip} 1}$ expression are maintained in $G_{0}$ by the sequential activity of distinct ubiquitin ligases during the cell cycle. As cells enter the cell cycle, cytoplasmic p27 $7^{\text {Kip1 }}$ is ubiquitinated by KPC (Kip1 ubiquitination-promoting complex) during $G_{1}$. KPC-mediated p27 ${ }^{\text {Kip } 1}$ proteolysis depends on p27 $7^{\text {Kip1 }}$ nuclear export, which occurs at $G_{0}$ exit/ $G_{1}$ phase entry. A bit later in the cell cycle, proteolysis of the remaining nuclear $\mathrm{p} 27^{\mathrm{Kip} 1}$ is triggered by phosphorylation on T187 and ubiquitination via interaction with the F-box protein Skp2 during early $S$ and $G_{2}$ phase (Kamura et al., 2004, Tsvetkov et al., 1999). In addition a third RING-H2-type ubiquitin ligase, Pirh2 ensures p27 ${ }^{\text {Kip1 }}$ ubiquitination both in the nucleus and the cytoplasm at late $G_{1}$ phase (Hattori et al., 2007). Based on the high levels of $p 27^{\text {Kip } 1}$ at $G_{0}$ and its destruction at $G_{1}$ entry and $G_{1}$ progression, a novel fluorescent cell cycle reporter was generated to separate $G_{0}$ and $G_{1}$ cells by fusing a fluorescent protein to an inactive form of $\mathrm{p} 27^{\mathrm{Kip} 1}$ protein that cannot bind to Cdk2, which we discuss in detail later.

\section{Using the pRb family to identify cells in $G_{0}$}

Cyclin/Cdk complexes and the activator forms of the transcription factor complex E2F/DP promote the progression of the cell cycle. By contrast, the Cyclin-dependent Kinase Inhibitors (CKIs) and the retinoblastoma protein-family members (pRB, p107 and p130) are negative regulators of cell cycle progression (Cobrinik, 2005, Vidal and Koff, 2000). Investigations into the function of the retinoblastoma proteins ( $p R B$ ), the first identified tumor suppressor (Huang et al., 1988, Trimarchi and Lees, 2002), showed that pRB is important for inhibiting cell cycle entry by binding and suppressing the transcription factor complex E2F/DP, which transcriptionally

\section{Prolifereation}
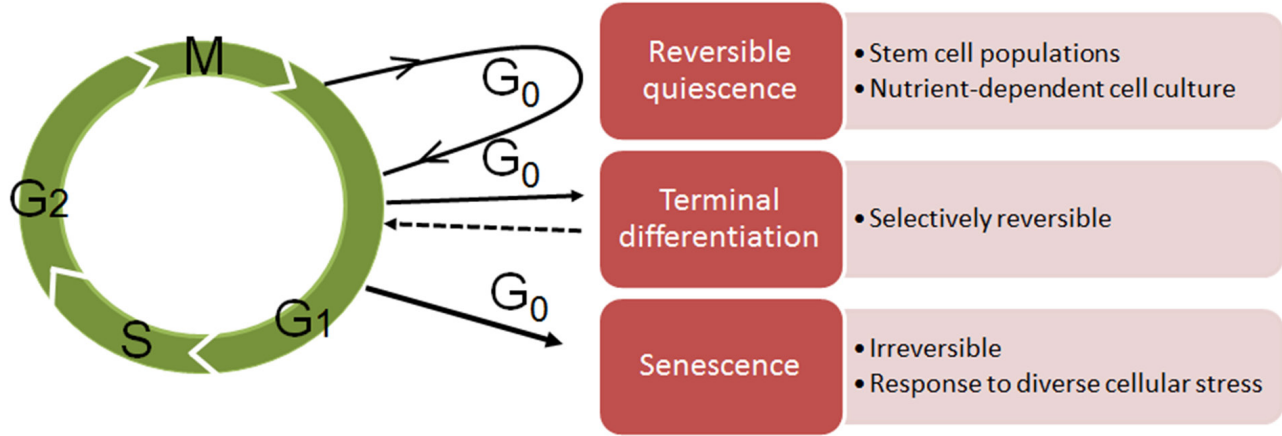

Fig. 1. Distinct states of $\mathbf{G}_{0}$. There are at least 3 distinct states of $G_{0}$ that vary in their reversibility. 
regulates hundreds of cell-cycle regulators (Burkhart and Sage, 2008, Tamrakar et al., 2000, van den Heuvel and Dyson, 2008). This repression is counteracted by the $\mathrm{G}_{1}$ Cyclin/Cdk complexes Cyclin E/Cdk2 and Cyclin D/Cdk4 which catalyze the phosphorylation of RB family members, resulting in the release of E2F/DP binding, allowing E2F/DP transcriptional activity (Du and Pogoriler, 2006). The active E2F/DP complexes promote Cyclin/Cdk expression transcriptionally, along with hundreds of other cell cycle genes, thus creating a positive feedback loop that promotes $G_{1}$ progression and robust commitment to cell cycle entry (Blais and Dynlacht, 2004, Trimarchi and Lees, 2002).

In the prevalent model of $\mathrm{G}_{0}-\mathrm{G}_{1}$ progression, $\mathrm{G}_{1}$ CyclinD-Cdk4/6 and CyclinE/Cdk2 complexes progressively phosphorylate RB resulting in the transition from an active, unphosphorylated $R B$, through a less active, hypo-phosphorylated form to drive $G_{1}$ entry, to a fully inactive hyper-phosphorylated $R B$ at the $G_{1}-S$ transition. However, recent biochemical studies in mouse embryonic fibroblasts (MEFs) showed that RB is exclusively mono-phosphorylated by CyclinD-Cdk4/6 on any one of $14 \mathrm{Cdk}$ phosphorylation sites that are spread throughout the protein at early $G_{1}$ phase. Surprisingly, the mono-phosphorylated RB still functions as a suppressor of E2F activity, in direct contrast to the prevalent model. At late $G_{1}$ phase, the mono-phosphorylated RB is further hyper-phosphorylated by the active CyclinE/Cdk2 complex to prevent its suppression of E2F activity, thereby allowing $\mathrm{G}_{1} / \mathrm{S}$ progression (Narasimha et al., 2014). Importantly, in quiescent or differentiating cells, RB remains in a repressive, un-phosphorylated form, which suggests that appearance of mono-phosphorylated $\mathrm{RB}$ could be an early mark of the $\mathrm{G}_{0}-\mathrm{G}_{1}$ transition. Any one of the potential 14 phospho-sites may be phosphorylated to generate the "active" form of RB, and therefore it is impossible to predict which one of the sites out of 14 will be monophosphorylated. Moreover, the mono-phosphorylated RB and unphosphorylated RB co-migrate on a traditional 1D SDS-acrylamide gel and require resolution by a two-dimensional isoelectric focusing (2D IEF) gel (Narasimha et al., 2014). Thus, it will be challenging to monitor mono-phosphorylated $\mathrm{RB}$ as a molecular marker for the $G_{0}-G_{1}$ transition in individual cells or in fixed tissue samples.

A different RB family member, p130 (RBL2), is the primary E2F complex repressor in certain quiescent cells (Sadasivam and Decaprio, 2013, Takahashi et al., 2000). The highly conserved p130/ E2F complex termed DP, RB-like, E2F, and MuvB (DREAM) is thought to be responsible for cell-cycle dependent gene repression in certain $\mathrm{G}_{0}$ cells, including human glioblastoma cells and human primary fibroblasts (Litovchick et al., 2011, Litovchick et al., 2007). Chromatin immunoprecipitation (ChIP) and Multidimensional Protein Identification Technology (MudPIT) have revealed that DREAM complex directly binds to 800 human promoters, and that most E2F cell cycle targets are repressed by p130/DREAM. The binding of p130 to DREAM is significantly stronger in $G_{0}$-arrested cells than in proliferating cells (Litovchick et al., 2007). At the $G_{0}-G_{1}$ transition, $G_{1}$ Cdks phosphorylate $p 130$, which triggers ubiquitination of $p 130$ via Skp2, thus leading to the release of E2F (Smith et al., 1996, Tedesco et al., 2002). Because p130 is high during quiescence and destroyed upon cell cycle entry, un-phosphorylated p130 could be an excellent positive marker for $G_{0}$ in certain reversibly quiescent cell types. For example, quiescent hematopoietic stem cells (HSCs) predominantly express p130 over other RB family members, and as HSCs exit from quiescence p130 decreases, possibly due to degradation (Passegue et al., 2005).

\section{Using a T-loop phosphorylation cascade to monitor the $G_{0}-G_{1}$ transition}

During $\mathrm{G}_{1}$ phase, CycD-Cdk4/6 kinase activity is responsible for mono-phosphorylation of $\mathrm{RB}$ to progressively promote the progression into $G_{1}$ phase. Therefore, the steps leading to activation of the Cdk4/6 complex are critical determinants of the $G_{0}-G_{1}$ transition. How is the Cdk4 or Cdk6 activated other than binding to CycD?

The typical Cdk catalytic subunit contains a 300 amino acid catalytic core which is inactive when monomeric (Morgan, 1995). Binding to a cyclin and phosphorylation of a conserved Thr residue in the activation loop (T-loop) are required to activate Cdk kinase activity. Phosphorylation of the Cdk T-loop is catalyzed by the Cdkactivating kinase (CAK) complex, composed of Cdk7, cyclin $\mathrm{H}$, and MAT-1. The catalytic component Cdk7 is expressed uniformly during the cell cycle, as Cdk7 also plays an essential role as a component of the general transcription factor $\mathrm{TFIIH}$, which phosphorylates the C- terminal domain (CTD) of the largest subunit of Pol II (Fisher, 2005, Larochelle et al., 1998, Merrick et al., 2008). Drosophila Cdk7 was first identified based on its requirement for proliferation, as it acts as a CAK to activate the Cdk1 complex in vivo (Larochelle et al., 1998). Indeed, the effects of Cdk7 loss on cell proliferation can be largely rescued by $\mathrm{Cdk} 2^{\mathrm{T} 160 \mathrm{E}}$ or $\mathrm{Cdk} 1^{\mathrm{T} 161 \mathrm{E}}$ phosphomimetic mutants in mouse embryonic fibroblasts (Ganuza et al., 2012). Thus, Cdk7 is essential for the activation of the cell cycle by phosphorylation of T-loop residues in Cdk2 or Cdk1.

It was recently uncovered that at early $G_{1}, \mathrm{Cdk} 4$ or Cdk6 activation is also largely dependent upon $\mathrm{Cdk} 7$ kinase activity in vivo (Schachter et al., 2013). Upon mitogenic signals, the Cdk7 activity is induced via the phosphorylation of its T-loop site by an unknown endogenous kinase, enabling Cdk7 to act in a T-loop cascade towards Cdk4/6. Once Cdk4 or Cdk6 are phosphorylated on their T-loop sites and bound to $\mathrm{CycD}$, they become active, but require continued Cdk7 activity to combat an unknown endogenous phosphatase that targets the unprotected T-loop site. Cdk7 plays an essential role in the activation and maintenance of Cdk4/6 activity to promote the $G_{0}-G_{1}$ transition. T-loop phosphorylation of Cdk7 and Cdk4 both increase at $G_{0}$ exit/ $G_{1}$ entry in vivo, which suggests a CDK activation cascade via sequential T-loop phosphorylation could underlie the $\mathrm{G}_{0}-\mathrm{G}_{1}$ transition. Consistent with this, stem cells lacking Cdk7 also lack the ability to repopulate tissues with rapid turnover suggesting this cascade is critical for cell cycle re-entry of stem cells (Ganuza et al., 2012).

This also suggests important roles for yet to be characterized kinases and phosphatases in the proliferation-quiescence decision. For example, what initiates $\mathrm{Cdk} 7$ activation at the $\mathrm{G}_{0}-\mathrm{G}_{1}$ transition? Is there another CAK? Or as in vitro studies have shown (Garrett et al., 2001), is Cdk7 a target of active Cdk2 in vivo? If so, Cdk2 activity levels very early after mitosis will be critical for the proliferationquiescence decision, a time much earlier in the cell cycle than its best known major role in the $G_{1}-S$ transition.

\section{Developmental regulation of the proliferation- quiescence decision}

As tissues mature in development, most cells differentiate into specialized cell types and slow or stop proliferation and contribute to organ function. Most adult animal cells have stopped dividing and enter $G_{0}$, where many will remain for lifetime of the organism. However, it remains unclear why or how cells choose to enter $G_{0}$ 
during development, and how certain developmental signals, tissue damage or nutrient conditions can trigger specific quiescent cells to re-enter the cell cycle.

\section{The double-repression of E2F and Cyclin/Cdk activity}

Despite the central role for the RB family proteins in most models of cell cycle exit and quiescence, cell cycle exit can still occur without functional pocket proteins. In mouse embryonic development, removal of all three RB family members (in a triple knockout or TKO background) does not prevent cell cycle exit and differentiation in epithelial or neuronal progenitor cells (Wirt et al., 2010). In conditional triple knockout (cTKO) hepatocytes, deletion of the RB family causes a temporary cell-cycle re-entry, but eventually cTKO hepatocytes stably exit the cell cycle (Ehmer et al., 2014). This is consistent with the finding that hyperactivation of the E2F transcription factor complex in Drosophila can only temporarily delay cell cycle exit, with cells arresting in $G_{0}$ after only 1-2 extra rounds of division (Buttitta et al., 2007). Thus additional mechanisms must exist to actively promote quiescence in differentiating cells in vivo.

$\mathrm{CKI}$ expression is commonly associated with $\mathrm{G}_{0}$. Not surprisingly, TKO mouse embryonic fibroblasts still exit cell cycle under serum starvation, but with high p27 ${ }^{\text {Kip } 1}$, p2 $1^{\text {Cip1 }}$ levels. This implies that CKIs may act as central mediators of cell cycle arrest in the absence of functional pocket proteins (Foijer et al., 2005). In mice deletion of $\mathrm{p}_{21^{\mathrm{Cip}} 1}$ induces proliferation in hippocampal neurons, indicating that $p 21^{\text {Cip } 1}$ is required for $G_{0}$ in specific differentiating neurons during development (Pechnick et al., 2008). Loss of $\mathrm{p} 21^{\mathrm{Cip} 1}$ or $\mathrm{p} 27^{\mathrm{Kip} 1}$ also disrupts the proper cycle exit of differentiating cardiomyocytes of newborn mice (Tane et al., 2014), resulting in altered DNA content. However these disruptions do not eliminate cell cycle exit altogether. For example, loss of all three CKI proteins (p21 ${ }^{\mathrm{Cip} 1}, \mathrm{p} 27^{\mathrm{Kip} 1}$ and $\mathrm{p} 57^{\mathrm{Kip} 2}$ ) in the spinal cord delays, but does not prevent cell cycle exit during neurogenesis (Gui et al., 2007). This is consistent with the finding in Drosophila that, the sole Cip/ Kip-type CKI, Dacapo (Dap), is largely dispensable for most cell cycle exit in Drosophila tissues after embryogenesis, including eye and wing development (Buttitta et al., 2007, Firth and Baker, 2005). Instead the Rb family and CKIs play overlapping roles in control of cell cycle exit in vivo. In animals ranging from mice to Drosophila to $C$. elegans, the loss of Rb family members and CKIs simultaneously leads to further proliferation in tissues that should enter $\mathrm{G}_{0}$ during development (Boxem and van den Heuvel, 2001, Firth and Baker, 2005, Yeh et al., 2007, Zindy et al., 1999).

\section{Looking beyond the pRb family and CKIs in quiescence}

The proteolysis of cyclins and their regulators ensures the proper temporal order of cell cycle events as well as the entry into quiescence. The two major protein degradation complexes involved in cell cycle regulation are Skp-Cullin-F-box (SCF) complexes for $\mathrm{G}_{1}$-S phase progression and the APC/C (the Anaphase-Promoting Complex/Cyclosome) for the completion of mitosis and entry into quiescence. The SCF complex consists of four subunits: Skp1 (scaffold protein), Cul1 (scaffold protein), RING-finger component (Rbx1), and a variable adaptor protein or F-box protein. The F-box proteins are E3 ubiquitin ligases that target a discrete number of specific substrates through protein-protein interactions. The F-box proteins Skp2 and Fbw7 target multiple cell cycle regulators. Skp2 mediates the degradation of the CDK inhibitors p21 Cip1, p27 Kip1 and $\mathrm{p} 57^{\mathrm{Kip} 2}$, as well as the Rb-family member $\mathrm{p} 130$, to promote

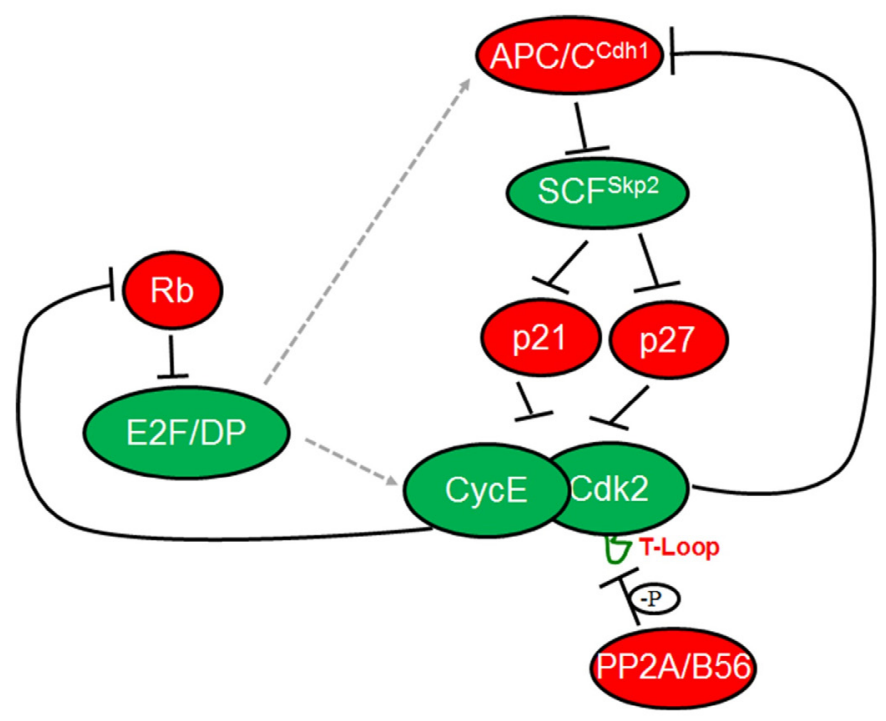

Fig. 2. A regulatory network influencing the proliferation-quiescence decision. Complexes impacting the proliferation-quiescence transition during development are shown with negative (red) and positive (green) cell cycle regulators. Several studies suggest redundancy of negative regulators ensures robust cell cycle exit upon terminal differentiation. Regulation may act transcriptionally (dashed lines) as well as post-transcriptionally (solid lines) and includes both positive and negative feedback loops.

$\mathrm{G}_{1}$ to $\mathrm{S}$ progression (Cardozo and Pagano, 2004, Tedesco et al., 2002, Willems et al., 2004). While Fbw7 targets several protooncogenes, including CycE, MYC, JUN and Notch (Koepp et al., 2001, Welcker and Clurman, 2008). In the regulation of the cell cycle, Fbw7 specifically targets phosphorylated CycE for degradation, which is high during the $\mathrm{G}_{1}-\mathrm{S}$ transition due to Cdk2 kinase complex activity (Clurman et al., 1996, Koepp et al., 2001). Mutations in Fbw7 have been found in several human cancers (Moberg et al., 2001), and Fbw7 mutations in mice and Drosophila, lead to additional proliferation and can delay entry into $\mathrm{G}_{0}$ in certain cell types (Moberg et al., 2001, Onoyama et al., 2007).

The APC/C is an E3 ubiquitin ligase complex whose activation requires the phosphorylation of specific subunits and the binding of a co-activator, either Cdc20 (or Fizzy; Fzy) or Cdh1 (or Fizzy-related; Fzr) for full activity. The APC/C complex is important to coordinate mitotic exit and quiescence (Clijsters et al., 2013, Sigrist and Lehner, 1997). During mitosis, APC/C ${ }^{\mathrm{Cdc} 20}$ complex promotes mitotic exit by degrading key substrates such as the mitotic cyclins and the replication licensing inhibitor Geminin, which usually accumulate during the S, G2, and early mitotic phases (McLean et al., 2011, Penas et al., 2011). In contrast, APC/C ${ }^{\text {Chn } 1}$ plays a major role after mitotic exit in maintaining quiescence and preventing precocious DNA replication (Eguren et al., 2011). Work from different groups also suggests the proliferation-quiescence transition and cell cycle exit requires the activity of APC/C ${ }^{\text {Chn } 1}$ complex (Buttitta et al., 2010, Cappell et al., 2016, Garcia-Higuera et al., 2008, Ruggiero et al., 2012, Tanaka-Matakatsu et al., 2007, The et al., 2015). What roles could the APC/C play to promote $\mathrm{G}_{0}$ ? One important target of the $\mathrm{APC} / \mathrm{C}$ is Skp2, which leads to the ubiquitination and degradation of the negative cell cycle regulators, $\mathrm{p} 27^{\mathrm{Kip} 1}$ and $\mathrm{p} 21^{\mathrm{Cip} 1}$. Thus high activity of APC/C not only leads to degradation of mitotic cyclins (Sigrist and Lehner, 1997), but also stabilizes CKIs to prevent cell 
cycle progression (Binne et al., 2007). Therefore, the cell cycle protein degradation machinery adds yet another layer of $G_{0}$ regulation.

Inhibition of APC/C activity also cooperates with the loss of other negative cell cycle regulators such as loss of RB family members to compromise cell cycle exit. For example, in $C$. elegans double mutants of RB and the APC/C activator Cdh1 exhibit aberrant expression of $S$ phase genes in differentiated muscle cells (The et al., 2015). In Drosophila, repression of APC/C activity together with aberrant $\mathrm{E} 2 \mathrm{~F}$ activity is able to bypass permanent cell cycle exit in the wing (Buttitta et al., 2010). This indicates that APC/C activity is required to limit the accumulation of cyclins and other essential E2F targets that promote active proliferation. CycE/ Cdk2 activity has been shown to inhibit APC/C activity (Reber et al., 2006, Sigrist and Lehner, 1997) thus, the high APC/C activity in quiescent, differentiating cells may also increase the threshold level of CycE required to suppress $A P C / C$ and initiate re-entry

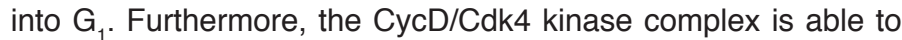
phosphorylate both $\mathrm{RB}$ and $\mathrm{APC} / \mathrm{C}^{\mathrm{Cah} 1}$ in vitro, resulting in their inactivation (The et al., 2015). Thus, one attractive model for cell cycle re-entry from $G_{0}$ is that $D$-type cyclins phosphorylate and abolish Cdh1 activity towards Skp2, and thereby allowing SCFSkp2 complex to degrade CKIs, resulting in high CycE/Cdk2 complex activity, which further inhibits the APC/C activity to push cell cycle re-entry (Bashir et al., 2004, Wei et al., 2004). Thus, Rb-mediated transcriptional repression and stable CKI expression, protected by the APC/C complex, all impinge upon the restriction of $G_{1}$ cyclin/ Cdk activity to promote cell cycle exit and a stable state of $G_{0}$ or quiescence (Fig.2).

\section{Threshold models of the Proliferation-Quiescence decision suggest different states of $G_{0}$}

Arecent single-cell study using a live-cell sensor for Cdk2 activity revealed an unexpected bifurcation in Cdk2 activity after mitosis in individual cells. In this study, individual cells within a clonal population were shown to exhibit different levels of Cdk2 activity after mitosis, and the level of Cdk2 activity was strongly correlated with the subsequent decision of whether to enter the next cell cycle or
A

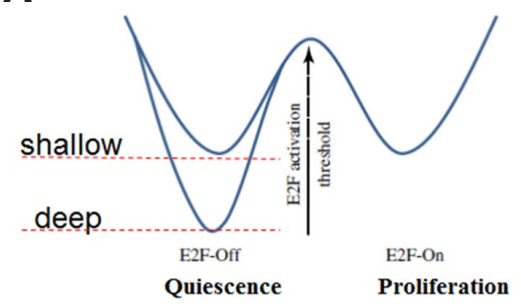

The Rb-E2F bistable switch model
The p21-Cdk2 model

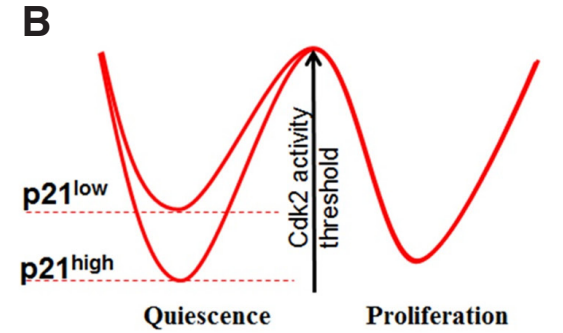

enter into temporary quiescence. The conclusion is that cells with higher Cdk2 activity after mitosis commit to enter the next cycle while cells with low Cdk2 activity enter a transient $G_{0}$-like state, even in a clonal population, in the presence of abundant nutrients (Spencer et al., 2013). The relative percentage of cells that enter $\mathrm{G}_{0}$-like state after mitosis varies in different cell types and culture conditions, suggesting many signaling inputs likely influence the proliferation-quiescence decision. This is consistent with findings in several cancer cell lines, suggesting some cancer cells enter quiescence, even under full nutrient conditions while others do not (Dey-Guha et al., 2011). This creates a heterogeneous population even within clonal cell lines, where some cells are actively cycling while others enter and leave temporary quiescent states. This leads to a situation termed 'proliferative heterogeneity', where different cells within a genetically identical population proliferate at different rates - which is readily visible in live cell imaging studies but becomes masked in non single-cell studies. A study in search of the regulatory mechanism for proliferative heterogeneity in clonal cell lines suggested that the relative levels of p21 ${ }^{\text {Cip } 1}$ and Cdk2 in individual cells and cell lines are responsible for the level of proliferative heterogeneity and the decision to proliferate or to enter quiescence in a human breast epithelial cell line (Overton et al.,

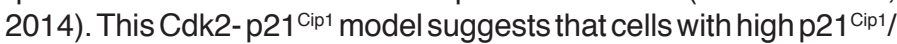
low Cdk2 activity are more likely to remain in a steady quiescent state, while cells with low p21 Cip $1 /$ high Cdk2 activity tend to rapidly commit to the next cycle after mitosis. Thus the threshold of Cdk2 activity set by its inhibitor $\mathrm{p} 21^{\mathrm{cip}}$ determines the proliferationquiescence decision. This raises intriguing questions about how p21 $1^{\mathrm{Cip} 1}$ is regulated and whether its levels oscillate between cycles or are stochastically regulated to create the proliferative heterogeneity observed in many cell lines, including cancer cells. While p21 $1^{\text {cip } 1}$ may be critically important for the proliferation-quiescence decision in some cell contexts, many cells deficient in p2 $1^{\text {cip } 1}$, such as MEFs can still enter quiescence even in low serum conditions. This suggests that mechanisms independent of $\mathrm{p} 21^{\text {cip } 1}$ must also contribute to the decision to enter quiescence or proliferate in the next cell cycle.

Indeed, another regulatory threshold model for the proliferationquiescence decision, has been proposed (Yao et al., 2008). In this Rb-E2F bistable model, the two steady states are based upon E2F complex transcription factor activity (E2F-Off and E2F-On), which define cellular quiescence and proliferation, respectively. The 'barrier' that separates the two states is the E2F activation threshold, and cells need to accumulate enough E2F activity to transit from quiescence to proliferation. Cells under different environmental conditions or with different cell types are likely to have variable E2F activation thresholds. The model predicts that cells with a higher E2F activation threshold are in a deeper
C

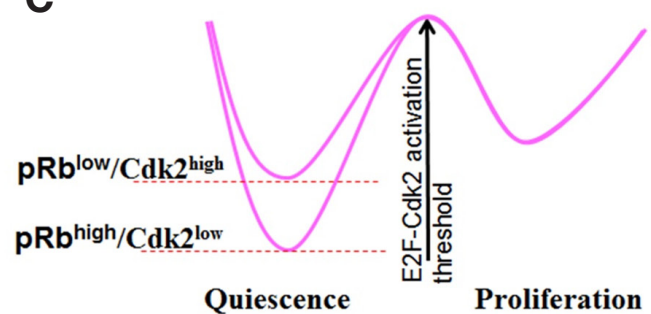

Fig. 3. Threshold models for the proliferation-quiescence decision. (A) An E2F activation threshold model predicts multiple states of quiescence (shallow or deep) may exist. (B) A Cdk2 activity threshold model predicts the ratio of endogenous p21:Cdk2 plays a role in determining the co-existence of proliferative and quiescent states. (C) An integration of these two models, taking into account the impact of Cdk2 activity on RB activity, illustrates how p21/active RB levels could influence the proliferation-quiescence decision and lead to multiple states of quiescence. The figure is adapted from G. Yao, Interface Focus. 4: 20130074 (2014). 
quiescence. This means that cells spend longer time to gain enough E2F activity in order to switch from E2F-Off/ quiescence to E2F-On/ proliferation, whereas cells in shallow quiescence are more likely to re-enter cell cycle at a faster rate. Thus varying levels of quiescence may exist in an asynchronous cell population, which may explain the observation of a bifurcation of the proliferation-quiescence decision observed by Spencer et al., under full nutrient conditions. These observations raise the question of whether multiple states of quiescence may be a source of proliferative heterogeneity. These two models both suggest that the proliferation-quiescence decision depends upon a bistable model with thresholds set by both positive and negative cell cycle regulators (Fig.3). Does this suggest that asynchronously growing cell populations constantly make the proliferation-quiescence decision, even under full nutrient conditions (Spencer et al., 2013)? If so, we may want to redraw the cell cycle to include varying lengths of $G_{0}$ as a normal part of the cell cycle (Fig. 4).

\section{A distinct proliferation-quiescence decision point (Q- point) in the cell cycle}

In cell culture normal proliferation is driven by environmental mitogenic stimuli. This includes mitogens such as EGF and other signaling molecules provided in serum. While in vivo, cell cycle progression is driven (or inhibited) by local signaling molecules used during development, in wound healing, or to maintain normal tissue homeostasis. As cells terminally differentiate in vivo, the signaling environment changes to downregulate mitogens and promote signaling that favors cell cycle exit. Thus, understanding the cell cycle response to the deprivation of mitogenic stimuli in cell culture may be useful to understand some of the mechanisms contributing to cell cycle exit in vivo during development. Serum starvation is commonly used to synchronize cell proliferation to

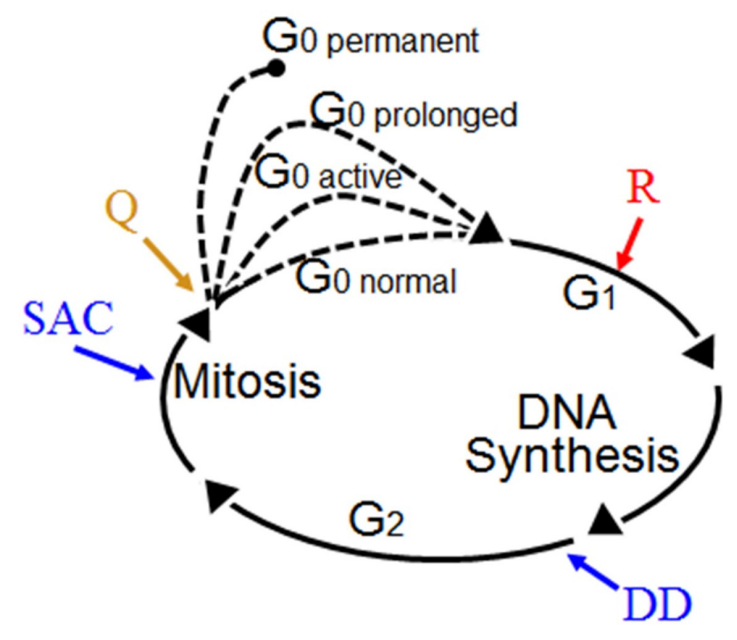

Fig. 4. Checkpoints throughout the cell cycle. The red arrow denotes the Restriction Point (R), while the yellow arrow denotes the proliferationquiescence decision point (Q). Other cell cycle checkpoints, such as the DNA damage checkpoint in $G_{2}\left(D D\right.$, which may also occur in $\left.G_{1}\right)$, and spindle checkpoint (SAC) are in blue. The variation in $G_{0}$ length in vivo or under full nutrient conditions is depicted as dashed paths between $M$ and $G$ phases. This model suggests all cells may go through a transient $G_{0}$ state labeled "G normal." arrest cells in $G_{0}$ phase and the response to serum starvation was used to establish the restriction point $(R)$ in the cell cycle, commonly assumed to be the proliferation-quiescence decision point. To define R, work by Dr. Pardee in the 1970s, suggested that cells can shift between proliferation and quiescence up to a certain point in the $G_{1}$ phase, the barrier or checkpoint $R$. If cells progress beyond $R$ in $\mathrm{G}_{1}$, even with serum deprivation, cells will commit to the next cycle (Pardee, 1974). A bit later in the 1980s, time-lapse imaging of mouse Swiss 3T3 cells revealed that a brief serum deprivation right after mitosis will arrest cells in quiescence $/ G_{0}$, accompanied by the reduction in protein synthesis. Importantly, only cells less than 3-4 hours beyond the completion of the last mitosis entered into quiescence in response to serum withdrawal, whereas cells beyond $4 \mathrm{hr}$ from the last mitosis were able to complete the rest of cell cycle in the absence of serum (Larsson et al., 1985). The $G_{1}$ phase was therefore subdivided into two physical phases: $G_{1}$ "postmitosis" and G, "pre-DNA synthesis", which are separated by the restriction point, serving as the presumed decision point for cells responding to mitogenic signals. But recent studies suggest that the proliferation-quiescence decision point actually occurs prior to the passage of cells through $G_{1}$, either during $G_{2}$ phase, where postmitotic Cdk2 activity levels may be set up or immediately after mitosis when the bifurcation in Cdk2 activity can be measured (Naetar et al., 2014, Spencer et al., 2013). This indicates the existence of another proliferation-quiescence decision point, one we label as $Q$, that is distinct from the later $R$ in $G_{1}$ (Fig. 4). $Q$ is associated with a bifurcation in Cdk2 activity, while $R$ is associated with a bifurcation in Rb-E2F activity (Yao et al., 2008). Both decision points are regulated by a shared pathway, the Cdk2-RbE2F pathway and thus can reflect different behaviors of the same regulatory pathway under different conditions (Zhang, 2013). Q operates during cycling under full nutrient conditions while $\mathrm{R}$ becomes evident in response to serum starvation. However results from Spencer et al., suggest that $Q$ and $R$ remain distinct, in that cells with high Cdk2 at the $Q$ point do not enter quiescence if they are subsequently deprived of serum before reaching $R$. Instead such conditions lead the Cdk2-high cells to enter and complete an additional cell cycle before entering quiescence at $\mathrm{R}$ in response to serum starvation. This is in contrast to prior models of $R$ and a model where $Q$ and $R$ act as distinct, subsequent "quiescence checkpoints" during the cell cycle (Fig.4), and may instead be the result of an "On" or "Off" state of the Cdk2-RB-E2F axis from $M-G_{1}$ (Zhang, 2013). It may also be that the $\mathrm{G}_{0}$-like state of Cdk2-low cells and $G_{0}$ entry at $R$ in response to serum starvation are in fact distinct $G_{0}$ states. This will require further live, single-cell studies with $G_{0}$-quiescence sensors described in the following section to resolve what constitutes a prolonged $M-G_{1}$ phase from entry into $\mathrm{G}_{0}$ or multiple states of $\mathrm{G}_{0}$.

We recently revealed a function for the PP2A/B56 complex in modulating Cdk2 activity and quiescence entry during development, just after the final mitosis preceding a developmentally regulated $\mathrm{G}_{0}$ entry, in Drosophila wings and eyes (Sun and Buttitta, 2015). Our work suggests that PP2A/B56 acts during the final cell cycle in vivo, independent of RB/E2F levels, to promote timely entry into quiescence. Our results are consistent with a model where PP2A/ B56 regulates Cdk2 activity by removing an activating phosphorylation in the Cdk2 T-loop activation site during or right after mitosis. This would cause a rapid drop in Cdk2 activity during the bifurcation described by Spencer et al., which we believe essential for timely 
quiescence entry in developing tissues. Of course it is also possible that in different biological contexts PP2A acts upon different targets to modulate the proliferation-quiescence transition. For example, an alternate model for PP2A/B56 acting via Ras signaling and Myc during $\mathrm{G}_{2}$ phase to modulate quiescence in human cells has also been proposed (Naetar et al., 2014). However in all these recent models, the regulatory machinery seems to ultimately impinge upon Cdk2 activity levels, either directly or indirectly at the proliferation-quiescence decision point (Q) just after mitosis, and prior to the Restriction point in $\mathrm{G}_{1}$ phase (Fig.4).

\section{Biosensor techniques to monitor the Proliferation- Quiescence decision}

In order to further investigate the features of the proliferationquiescence decision, and to test whether multiple states of quiescence may be a source of proliferative heterogeneity, we need to be able to identify $G_{0}$ cells and monitor $G_{0}$ entry at the proliferation-quiescence transition during a designated period of time. Recently, a novel cell cycle indicator, mVenus-p27K- (p27K), was generated to specifically label quiescent cells (Oki et al., 2014). This probe is a fusion protein consisting of a fluorescent protein mVenus and a Cdk binding defective mutant of p27. p27 accumulates during quiescence, and its degradation is triggered upon cell cycle entry by two ubiquitin ligases, KPC and SCFSkp2. The Kip1 ubiquitination-promoting complex (KPC) is an E3 ligase complex that triggers p27 degradation at $G_{0}-G_{1}$ transition, while the SCF ${ }^{\text {Skp2 }}$ complex triggers degradation of nuclear p27 during the S/ G2/M phases (Kamura et al., 2004). When p27K' is combined with another cell cycle reporter for $G_{1}$ phase, mCherry-hCdt1(30/120), $G_{0}$ vs. $G_{1}$ can be distinguished (Oki et al., 2014). The mCherry$\mathrm{hCdt1}(30 / 120)$ reporter is a fusion of mCherry to the degron from the human replication licensing factor $\mathrm{Cdt} 1$ ( $\mathrm{hCdt} 1$ ) which is targeted for degradation by the SCF ${ }^{S k p 2}$ complex at the S/G2/M phases. Thus, mVenus-p27K- together with mCherry-hCdt1(30/120) label cells from just after the completion of mitosis until early $S$ phase in distinct colors, which now provides the possibility to examine the proliferation- quiescence decision under different conditions via live imaging or FACS analysis without chemical or nutrient-deprivation synchronization. In addition this reporter works in transgenic mice to reveal resting stem cells, such as muscle satellite cells, opening the door for in vivo examinations of stem cell quiescence (Oki et al., 2014).

Unfortunately the mVenus-p27K- probe may be not feasible for all cell types. It is reported the osteosarcoma cell line, U2O2 cell line transduced with this reporter displays defects in proliferation, while NIH3T3 cells as well as several other cell lines transduced with mVenus-p27K- proliferate normally without detectable defects in cell cycle regulation (Oki et al., 2014). This could be due to the ectopic expression of the mVenus-p27K- fusion protein, which could be expected to maintain or carry out Cdk-independent functions of p27 raging from cytoskeletal roles to unexpected sequestration of non-Cdk binding partners (Serres et al., 2012, Sharma et al., 2012). Thus, in certain contexts unexpected activities of ectopically expressed reporters may generate confounding effects on the cell cycle.

To get around the problem of expressing an ectopic fusion reporter protein one would rather tag the endogenous protein. An advanced toolkit called "eFlut" has been recently established to do just that (Stewart-Ornstein and Lahav, 2016). This toolkit uses a novel plasmid set and Cas9 reagents to efficiently deliver fluorescent tags into endogenous gene sites in cell lines. This provides several advantages over transducing cells with viruses containing ectopic cell cycle reporters. First, there is less variability in expression levels since the endogenous protein is tagged versus the random integration of a virally encoded reporter into the cell's genome. This will likely favor more precise analysis of protein dynamics during the cell cycle. In addition this avoids the issues described above, where expression of the reporter itself has unexpected biological effects possibly leading to alterations in the cell cycle. However one obvious drawback of fluorescently tagging endogenous proteins via eFlut may be that important cell cycle proteins with lower expression levels will be difficult to monitor.

To show the potential of the eFlut toolkit, Stewart-Ornstein and Lahav used eFlut to investigate the regulation of the CKI p21 Cip1 by quantitative $\mathrm{p} 21^{\mathrm{Cip} 1}$-YFP measurements at the single cell level. Interestingly, the $\mathrm{p} 21^{\mathrm{Cip} 1}$ protein accumulation dynamics and timing varies substantially between individual cells, and even between sister cells. This further indicates the existence of proliferative heterogeneity within clonal cell populations, and importantly is consistent with the threshold model of p21-Cdk2 suggested to be responsible for the proliferative heterogeneity (Overton et al., 2014). The eFlut toolkit should provide further opportunities to systematically characterize the dynamics of cell cycle networks that impinge upon the proliferation-quiescence transition, which will help us to finally understand how cell cycle machinery responds to environmental cues or developmental signals upon the proliferation-quiescence decision.

\section{Future outlook}

With the new molecular markers, live cell imaging and single cell assays discussed here, several outstanding questions regarding $\mathrm{G}_{0}$ will hopefully be addressed. Perhaps most pressing is the need to finally understand the differences between reversible quiescence and permanent $G_{0}$. Are there distinct cell cycle regulatory mechanisms required for permanent or prolonged cell cycle exit of postmitotic cells versus the readily reversible quiescence of stem cells or nutrient deprived cells? One possibility is that the prolonged or permanent $G_{0}$ of terminally differentiated cells may simply be due to multiple redundant mechanisms, cooperating simultaneously to promote a more robust cell cycle exit in postmitotic cells. Indeed, some of the studies described here, using double or triple mutants support this idea. But there is also evidence that additional factors involved in terminal differentiation, such as differentiationassociated chromatin changes, may come into play to impact cell cycle regulation and promote prolonged or permanent $\mathrm{G}_{0}$ (Pajalunga et al., 2010, Peric-Hupkes et al., 2010, Ruijtenberg and van den Heuvel, 2015). Asecond outstanding question regards proliferative heterogeneity in clonal cell culture lines and whether the choice to enter states of temporary $G_{0}$ are stochastic, or whether there is some sort of inheritance (possibly epigenetically) of a slowly vs. rapidly proliferating state. Cell lineage tracing tools may be combined with eFlut or the new quiescence marker mVenus-p27K-to address this issue. This may be a particularly important question for cancer cells, where slow cycling sub-populations may contribute to issues of chemotherapy-resistance or tumor dormancy and recurrence. Finally, we hope future studies will begin to address the question 
of how a stable $G_{0}$ state is maintained long-term during the lifetime of an organism, such as that of terminally differentiated neurons, and whether/how the $\mathrm{G}_{0}$ state may change with age to possibly become more or less flexible.

\section{Acknowledgements}

Work in the Buttitta Lab is supported by the National Institutes of Health (R21AG047931 and R00GM086517) and the American Cancer Society (RSG-15-161-01-DDC). We thank an anonymous reviewer for helpful comments on this manuscript. We apologize to our many cell cycle colleagues whose work could not be cited due to citation restrictions.

\section{References}

BASHIR, T., DORRELLO, N.V., AMADOR, V., GUARDAVACCARO, D. and PAGANO, M. (2004). Control of the SCF(Skp2-Cks1) ubiquitin ligase by the APC/C(Cdh1) ubiquitin ligase. Nature 428: 190-193.

BINNE, U.K., CLASSON, M.K., DICK, F.A., WEI, W., RAPE, M., KAELIN, W.G., JR., NAAR, A.M. and DYSON, N.J. (2007). Retinoblastoma protein and anaphasepromoting complex physically interact and functionally cooperate during cell-cycle exit. Nat Cell Biol 9: 225-232.

BLAIS, A. and DYNLACHT, B.D. (2004). Hitting their targets: an emerging picture of E2F and cell cycle control. Curr Opin Genet Dev 14: 527-532.

BOXEM, M. and VAN DEN HEUVEL, S. (2001). lin-35 Rb and cki-1 Cip/Kip cooperate in developmental regulation of G1 progression in C. elegans. Development 128: 4349-4359.

BURKHART, D.L. and SAGE, J. (2008). Cellular mechanisms of tumour suppression by the retinoblastoma gene. Nat Rev Cancer 8: 671-682.

BUTTITTA, L.A., KATZAROFF, A.J. and EDGAR, B.A. (2010). A robust cell cycle control mechanism limits E2F-induced proliferation of terminally differentiated cells in vivo. J Cell Biol 189: 981-996.

BUTTITTA, L.A., KATZAROFF, A.J., PEREZ, C.L., DE LA CRUZ, A. and EDGAR, B.A. (2007). A double-assurance mechanism controls cell cycle exit upon terminal differentiation in Drosophila. Dev Cell 12: 631-643.

CAPPELL, S.D., CHUNG, M., JAIMOVICH, A., SPENCER, S.L. and MEYER, T. (2016). Irreversible APC(Cdh1) Inactivation Underlies the Point of No Return for Cell-Cycle Entry. Cell 166: 167-180

CARDOZO, T. and PAGANO, M. (2004). The SCF ubiquitin ligase: insights into a molecular machine. Nat Rev Mol Cell Biol 5: 739-751.

CHANDLER, H. and PETERS, G. (2013). Stressing the cell cycle in senescence and aging. Curr Opin Cell Biol 25: 765-771.

CHENG, T., RODRIGUES, N., SHEN, H., YANG, Y., DOMBKOWSKI, D., SYKES, M. and SCADDEN, D.T. (2000). Hematopoietic stem cell quiescence maintained by p21cip1/waf1. Science 287: 1804-1808.

CLIJSTERS, L., OGINK, J. and WOLTHUIS, R. (2013). The spindle checkpoint, $\mathrm{APC} / \mathrm{C}(\mathrm{Cdc} 20)$, and $\mathrm{APC} / \mathrm{C}(\mathrm{Cdh} 1)$ play distinct roles in connecting mitosis to $\mathrm{S}$ phase. J Cell Biol 201: 1013-1026.

CLURMAN, B.E., SHEAFF, R.J., THRESS, K., GROUDINE, M. and ROBERTS, J.M. (1996). Turnover of cyclin $E$ by the ubiquitin-proteasome pathway is regulated by cdk2 binding and cyclin phosphorylation. Genes Dev 10: 1979-1990.

COBRINIK, D. (2005). Pocket proteins and cell cycle control. Oncogene24:2796-2809.

COLLER, H.A., SANG, L. and ROBERTS, J.M. (2006). A new description of cellular quiescence. PLoS Biol 4: e83.

DENG, C., ZHANG, P., HARPER, J.W., ELLEDGE, S.J. and LEDER, P. (1995). Mice lacking p21CIP1/WAF1 undergo normal development, but are defective in G1 checkpoint control. Cell 82: 675-684.

DEY-GUHA, I., WOLFER, A., YEH, A.C., J, G.A., DARP, R., LEON, E., WULFKUHLE, J., PETRICOIN, E.F., 3RD, WITTNER, B.S. and RAMASWAMY, S. (2011). Asymmetric cancer cell division regulated by AKT. Proc Natl Acad Sci USA 108: 12845-12850.

DIKOVSKAYA, D., COLE, J.J., MASON, S.M., NIXON, C., KARIM, S.A., MCGARRY, L., CLARK, W., HEWITT, R.N., SAMMONS, M.A., ZHU, J. et al., (2015). Mitotic Stress Is an Integral Part of the Oncogene-Induced Senescence Program that Promotes Multinucleation and Cell Cycle Arrest. Cell Rep 12: 1483-1496.

DU, W. and POGORILER, J. (2006). Retinoblastoma family genes. Oncogene 25:
5190-5200.

DULIC, V., STEIN, G.H., FAR, D.F. and REED, S.I. (1998). Nuclear accumulation of p21Cip1 at the onset of mitosis: a role at the G2/M-phase transition. Mol Cell Biol 18: 546-557.

EGUREN, M., MANCHADO, E. and MALUMBRES, M. (2011). Non-mitotic functions of the Anaphase-Promoting Complex. Semin Cell Dev Biol 22: 572-578.

EHMER, U., ZMOOS, A.F., AUERBACH, R.K., VAKA, D., BUTTE, A.J., KAY, M.A. and SAGE, J. (2014). Organ size control is dominant over Rb family inactivation to restrict proliferation in vivo. Cell Rep 8: 371-381.

FERO, M.L., RIVKIN, M., TASCH, M., PORTER, P., CAROW, C.E., FIRPO, E. POLYAK, K., TSAI, L.H., BROUDY, V., PERLMUTTER, R.M. et al., (1996). A syndrome of multiorgan hyperplasia with features of gigantism, tumorigenesis, and female sterility in p27(Kip1)-deficient mice. Cell 85: 733-744.

FIRTH, L.C. and BAKER, N.E. (2005). Extracellular signals responsible for spatially regulated proliferation in the differentiating Drosophila eye. Dev Cell 8: 541-551.

FISHER, R.P. (2005). Secrets of a double agent: CDK7 in cell-cycle control and transcription. J Cell Sci 118: 5171-5180.

FOIJER, F., WOLTHUIS, R.M., DOODEMAN, V., MEDEMA, R.H. and TE RIELE, H. (2005). Mitogen requirement for cell cycle progression in the absence of pocket protein activity. Cancer Cell 8: 455-466.

FOX, D.T. and DURONIO, R.J. (2013). Endoreplication and polyploidy: insights into development and disease. Development 140: 3-12

FURUTACHI, S., MATSUMOTO, A., NAKAYAMA, K.I. and GOTOH, Y. (2013). p57 controls adult neural stem cell quiescence and modulates the pace of lifelong neurogenesis. EMBO J 32: 970-981.

GANUZA, M., SAIZ-LADERA, C., CANAMERO, M., GOMEZ, G., SCHNEIDER, R. BLASCO, M.A., PISANO, D., PARAMIO, J.M., SANTAMARIA, D. and BARBACID, M. (2012). Genetic inactivation of Cdk7 leads to cell cycle arrest and induces premature aging due to adult stem cell exhaustion. EMBO J 31: 2498-2510.

GARCIA-HIGUERA, I., MANCHADO, E., DUBUS, P., CANAMERO, M., MENDEZ, J., MORENO, S. and MALUMBRES, M. (2008). Genomic stability and tumour suppression by the APC/C cofactor Cdh1. Nat Cell Biol 10: 802-811.

GARRETT, S., BARTON, W.A., KNIGHTS, R., JIN, P., MORGAN, D.O. and FISHER, R.P. (2001). Reciprocal activation by cyclin-dependent kinases 2 and 7 is directed by substrate specificity determinants outside the T loop. Mol Cell Biol 21: 88-99.

GUI, H., LI, S. and MATISE, M.P. (2007). A cell-autonomous requirement for Cip/Kip cyclin-kinase inhibitors in regulating neuronal cell cycle exit but not differentiation in the developing spinal cord. Dev Biol 301: 14-26.

HATTORI, T., ISOBE, T., ABE, K., KIKUCHI, H., KITAGAWA, K., ODA, T., UCHIDA, C. and KITAGAWA, M. (2007). Pirh2 promotes ubiquitin-dependent degradation of the cyclin-dependent kinase inhibitor p27Kip1. Cancer Res 67: 10789-10795.

HUANG, H.J., YEE, J.K., SHEW, J.Y., CHEN, P.L., BOOKSTEIN, R., FRIEDMANN, T., LEE, E.Y. and LEE, W.H. (1988). Suppression of the neoplastic phenotype by replacement of the RB gene in human cancer cells. Science 242: 1563-1566.

KAMURA, T., HARA, T., MATSUMOTO, M., ISHIDA, N., OKUMURA, F., HATAKEYAMA S., YOSHIDA, M., NAKAYAMA, K. and NAKAYAMA, K.I. (2004). Cytoplasmic ubiquitin ligase KPC regulates proteolysis of p27(Kip1) at G1 phase. Nat Cell Biol 6: 1229-1235.

KIYOKAWA, H., KINEMAN, R.D., MANOVA-TODOROVA, K.O., SOARES, V.C. HOFFMAN, E.S., ONO, M., KHANAM, D., HAYDAY, A.C., FROHMAN, L.A. and KOFF, A. (1996). Enhanced growth of mice lacking the cyclin-dependent kinase inhibitor function of p27(Kip1). Cell 85: 721-732.

KOEPP, D.M., SCHAEFER, L.K., YE, X., KEYOMARSI, K., CHU, C., HARPER, J.W. and ELLEDGE, S.J. (2001). Phosphorylation-dependent ubiquitination of cyclin E by the SCFFbw7 ubiquitin ligase. Science 294: 173-177.

LAROCHELLE, S., PANDUR, J., FISHER, R.P., SALZ, H.K. and SUTER, B. (1998). Cdk7 is essential for mitosis and for in vivo Cdk-activating kinase activity. Genes Dev 12: 370-381.

LARSSON, O., ZETTERBERG, A. and ENGSTROM, W. (1985). Consequences of parental exposure to serum-free medium for progeny cell division. $J \mathrm{Cell} S \mathrm{Sci}$ 75: 259-268.

LITOVCHICK, L., FLORENS, L.A., SWANSON, S.K., WASHBURN, M.P. and DECAPRIO, J.A. (2011). DYRK1A protein kinase promotes quiescence and senescence through DREAM complex assembly. Genes Dev 25: 801-813.

LITOVCHICK, L., SADASIVAM, S., FLORENS, L., ZHU, X., SWANSON, S.K. 
VELMURUGAN, S., CHEN, R., WASHBURN, M.P., LIU, X.S. and DECAPRIO, J.A. (2007). Evolutionarily conserved multisubunit RBL2/p130 and E2F4 protein complex represses human cell cycle-dependent genes in quiescence. Mol Cell 26: 539-551.

MCLEAN, J.R., CHAIX, D., OHI, M.D. and GOULD, K.L. (2011). State of the APC/C: organization, function, and structure. Crit Rev Biochem Mol Biol 46: 118-136.

MERRICK, K.A., LAROCHELLE, S., ZHANG, C., ALLEN, J.J., SHOKAT, K.M. and FISHER, R.P. (2008). Distinct activation pathways confer cyclin-binding specificity on Cdk1 and Cdk2 in human cells. Mol Cell 32: 662-672.

MOBERG, K.H., BELL, D.W., WAHRER, D.C., HABER, D.A. and HARIHARAN, I.K. (2001). Archipelago regulates Cyclin E levels in Drosophila and is mutated in human cancer cell lines. Nature 413: 311-316.

MORGAN, D.O. (1995). Principles of CDK regulation. Nature 374: 131-134.

MUNOZ-ESPIN, D., CANAMERO, M., MARAVER, A., GOMEZ-LOPEZ, G., CONTRERAS, J., MURILLO-CUESTA, S., RODRIGUEZ-BAEZA, A., VARELA-NIETO, I., RUBERTE, J., COLLADO, M. et al., (2013). Programmed cell senescence during mammalian embryonic development. Cell 155: 1104-1118.

NAETAR, N., SOUNDARAPANDIAN, V., LITOVCHICK, L., GOGUEN, K.L., SABLINA, A.A., BOWMAN-COLIN, C., SICINSKI, P., HAHN, W.C., DECAPRIO, J.A. and LIVINGSTON, D.M. (2014). PP2A-Mediated Regulation of Ras Signaling in G2 Is Essential for Stable Quiescence and Normal G1 Length. Mol Cell 54: 932-945.

NARASIMHA, A.M., KAULICH, M., SHAPIRO, G.S., CHOI, Y.J., SICINSKI, P. and DOWDY, S.F. (2014). Cyclin D activates the Rb tumor suppressor by monophosphorylation. Elife 3: : 1068-1080.

OKI, T., NISHIMURA, K., KITAURA, J., TOGAMI, K., MAEHARA, A., IZAWA, K., SAKAUE-SAWANO, A., NIIDA, A., MIYANO, S., ABURATANI, H. et al., (2014). A novel cell-cycle-indicator, mVenus-p27K-, identifies quiescent cells and visualizes Go-G1 transition. Sci Rep 4: 4012.

ONOYAMA, I., TSUNEMATSU, R., MATSUMOTO, A., KIMURA, T., DE ALBORAN, I.M., NAKAYAMA, K. and NAKAYAMA, K.I. (2007). Conditional inactivation of Fbxw7 impairs cell-cycle exit during $T$ cell differentiation and results in lymphomatogenesis. J Exp Med 204: 2875-2888.

ORR-WEAVER, T.L. (2015). When bigger is better: the role of polyploidy in organogenesis. Trends Genet 31: 307-315.

ORTEGA, S., MALUMBRES, M. and BARBACID, M. (2002). Cyclin D-dependent kinases, INK4 inhibitors and cancer. Biochim Biophys Acta 1602: 73-87.

OVERTON, K.W., SPENCER, S.L., NODERER, W.L., MEYER, T. and WANG, C.L. (2014). Basal p21 controls population heterogeneity in cycling and quiescent cell cycle states. Proc Natl Acad Sci USA. 111: E4386-4393.

PAJALUNGA, D., PUGGIONI, E.M., MAZZOLA, A., LEVA, V., MONTECUCCO, A. and CRESCENZI, M. (2010). DNA replication is intrinsically hindered in terminally differentiated myotubes. PLoS One 5: e11559.

PARDEE, A.B. (1974). A restriction point for control of normal animal cell proliferation. Proc Natl Acad Sci USA 71: 1286-1290.

PARRY, D., MAHONY, D., WILLS, K. and LEES, E. (1999). Cyclin D-CDK subunit arrangement is dependent on the availability of competing INK4 and p21 class inhibitors. Mol Cell Biol 19: 1775-1783.

PASSEGUE, E., WAGERS, A.J., GIURIATO, S., ANDERSON, W.C. and WEISSMAN, I.L. (2005). Global analysis of proliferation and cell cycle gene expression in the regulation of hematopoietic stem and progenitor cell fates. $J$ Exp Med 202: 1599-1611.

PATERAS, I.S., APOSTOLOPOULOU, K., NIFOROU, K., KOTSINAS, A. and GORGOULIS, V.G. (2009). p57KIP2: "Kip"ing the cell under control. Mol Cancer Res 7: 1902-1919

PECHNICK, R.N., ZONIS, S., WAWROWSKY, K., POURMORADY, J. and CHESNOKOVA, V. (2008). p21Cip1 restricts neuronal proliferation in the subgranular zone of the dentate gyrus of the hippocampus. Proc Natl Acad SciUSA 105: 1358-1363.

PENAS, C., RAMACHANDRAN, V. and AYAD, N.G. (2011). The APC/C Ubiquitin Ligase: From Cell Biology to Tumorigenesis. Front Oncol 1: 60.

PERIC-HUPKES, D., MEULEMAN, W., PAGIE, L., BRUGGEMAN, S.W., SOLOVEI, I., BRUGMAN, W., GRAF, S., FLICEK, P., KERKHOVEN, R.M., VAN LOHUIZEN, M. et al., (2010). Molecular maps of the reorganization of genome-nuclear lamina interactions during differentiation. Mol Cell 38: 603-613.

POZAROWSKI, P. and DARZYNKIEWICZ, Z. (2004). Analysis of cell cycle by flow cytometry. Methods Mol Biol 281: 301-311.
REBER, A., LEHNER, C.F. and JACOBS, H.W. (2006). Terminal mitoses require negative regulation of $\mathrm{Fzr} / \mathrm{Cdh} 1$ by Cyclin $\mathrm{A}$, preventing premature degradation of mitotic cyclins and String/Cdc25. Development 133: 3201-3211.

RESTALL, I.J., PAROLIN, D.A., DANESHMAND, M., HANSON, J.E., SIMARD, M.A., FITZPATRICK, M.E., KUMAR, R., LAVICTOIRE, S.J. and LORIMER, I.A. (2015). PKCiota depletion initiates mitotic slippage-induced senescence in glioblastoma. Cell Cycle 14: 2938-2948.

RUGGIERO, R., KALE, A., THOMAS, B. and BAKER, N.E. (2012). Mitosis in neurons: Roughex and APC/C maintain cell cycle exit to prevent cytokinetic and axonal defects in Drosophila photoreceptor neurons. PLoS Genet 8: e1003049.

RUIJTENBERG, S. and VANDENHEUVEL, S. (2015). G1/S Inhibitors and the SWI/SNF Complex Control Cell-Cycle Exit during Muscle Differentiation. Cell 162: 300-313.

SADASIVAM, S. and DECAPRIO, J.A. (2013). The DREAM complex: master coordinator of cell cycle-dependent gene expression. Nat Rev Cancer 13: 585-595.

SAERA-VILA, A., KASPRICK, D.S., JUNTTILA, T.L., GRZEGORSKI, S.J., LOUIE, K.W., CHIARI, E.F., KISH, P.E. and KAHANA, A. (2015). Myocyte Dedifferentiation Drives Extraocular Muscle Regeneration in Adult Zebrafish. Invest Ophthalmol Vis Sci 56: 4977-4993.

SALAMA, R., SADAIE, M., HOARE, M. and NARITA, M. (2014). Cellular senescence and its effector programs. Genes Dev 28: 99-114.

SCHACHTER, M.M., MERRICK, K.A., LAROCHELLE, S., HIRSCHI, A., ZHANG, C., SHOKAT, K.M., RUBIN, S.M. and FISHER, R.P. (2013). A Cdk7-Cdk4 T-loop phosphorylation cascade promotes G1 progression. Mol Cell 50: 250-260.

SERRES, M.P., KOSSATZ, U., CHI, Y., ROBERTS, J.M., MALEK, N.P. and BESSON, A. (2012). p27(Kip1) controls cytokinesis via the regulation of citron kinase activation. J Clin Invest 122: 844-858.

SHARMA, S.S., MA, L., BAGUI, T.K., FORINASH, K.D. and PLEDGER, W.J. (2012) A p27Kip1 mutant that does not inhibit CDK activity promotes centrosome amplification and micronucleation. Oncogene 31: 3989-3998.

SIGRIST, S.J. and LEHNER, C.F. (1997). Drosophila fizzy-related down-regulates mitotic cyclins and is required for cell proliferation arrest and entry into endocycles. Cell 90: 671-681.

SMITH, E.J., LEONE, G., DEGREGORI, J., JAKOI, L. and NEVINS, J.R. (1996). The accumulation of an E2F-p130 transcriptional repressor distinguishes a GO cell state from a G1 cell state. Mol. Cell. Biol. 16: 6965-6976.

SOOS, T.J., KIYOKAWA, H., YAN, J.S., RUBIN, M.S., GIORDANO, A., DEBLASIO, A., BOTTEGA, S., WONG, B., MENDELSOHN, J. and KOFF, A. (1996). Formation of p27-CDK complexes during the human mitotic cell cycle. Cell Growth Differ 7: 135-146.

SPENCER, S.L., CAPPELL, S.D., TSAI, F.C., OVERTON, K.W., WANG, C.L. and MEYER, T. (2013). The proliferation-quiescence decision is controlled by a bifurcation in CDK2 activity at mitotic exit. Cell 155: 369-383.

STEWART-ORNSTEIN, J. and LAHAV, G. (2016). Dynamics of CDKN1Ain Single Cells Defined by an Endogenous Fluorescent Tagging Toolkit. Cell Rep 14: 1800-1811.

STORER, M., MAS, A., ROBERT-MORENO, A., PECORARO, M., ORTELLS, M.C., DI GIACOMO, V., YOSEF, R., PILPEL, N., KRIZHANOVSKY, V., SHARPE, J. et al., (2013). Senescence is a developmental mechanism that contributes to embryonic growth and patterning. Cell 155: 1119-1130.

SUGIURA, T., WANG, H., BARSACCHI, R., SIMON, A. and TANAKA, E.M. (2016) MARCKS-like protein is an initiating molecule in axolotl appendage regeneration. Nature 531: 237-240.

SUN, D. and BUTTITTA, L. (2015). Protein phosphatase 2A promotes the transition to G0 during terminal differentiation in Drosophila. Development 142: 3033-3045.

TAKAHASHI, Y., RAYMAN, J.B. and DYNLACHT, B.D. (2000). Analysis of promoter binding by the E2F and pRB families in vivo: distinct E2F proteins mediate activation and repression. Genes Dev 14: 804-816.

TAMRAKAR, S., RUBIN, E. and LUDLOW, J.W. (2000). Role of pRB dephosphorylation in cell cycle regulation. Front Biosci 5: D121-D137.

TANAKA-MATAKATSU, M., THOMAS, B.J. and DU, W. (2007). Mutation of the Apc1 homologue shattered disrupts normal eye development by disrupting $\mathrm{G} 1$ cell cycle arrest and progression through mitosis. Dev Biol 309: 222-235.

TANE, S., IKENISHI, A., OKAYAMA, H., IWAMOTO, N., NAKAYAMA, K.I. and TAKEUCHI, T. (2014). CDK inhibitors, p21 (Cip1) and p27(Kip1), participate in cell cycle exit of mammalian cardiomyocytes. Biochem Biophys Res Commun 443: 1105-1109.

TEDESCO, D., LUKAS, J. and REED, S.I. (2002). The pRb-related protein p130 
is regulated by phosphorylation-dependent proteolysis via the protein-ubiquitin ligase SCF(Skp2). Genes Dev 16: 2946-2957.

THE, I., RUIJTENBERG, S., BOUCHET, B.P., CRISTOBAL, A., PRINSEN, M.B., VAN MOURIK, T., KORETH, J., XU, H., HECK, A.J., AKHMANOVA, A. et al., (2015). $\mathrm{Rb}$ and $\mathrm{FZR} 1 / \mathrm{Cdh} 1$ determine CDK4/6-cyclin $\mathrm{D}$ requirement in $\mathrm{C}$. elegans and human cancer cells. Nat Commun 6: 5906.

TRIMARCHI, J.M. and LEES, J.A. (2002). Sibling rivalry in the E2F family. Nat Rev Mol Cell Biol 3: 11-20.

TSUE, T.T., WATLING, D.L., WEISLEDER, P., COLTRERA, M.D. and RUBEL, E.W. (1994). Identification of hair cell progenitors and intermitotic migration of their nuclei in the normal and regenerating avian inner ear. J Neurosci 14: 140-152.

TSVETKOV, L.M., YEH, K.H., LEE, S.J., SUN, H. and ZHANG, H. (1999). p27(Kip1) ubiquitination and degradation is regulated by the SCF(Skp2) complex through phosphorylated Thr187 in p27. Curr Biol 9: 661-664.

VAN DEN HEUVEL, S. and DYSON, N.J. (2008). Conserved functions of the pRB and E2F families. Nat Rev Mol Cell Biol 9: 713-724.

VIDAL, A. and KOFF, A. (2000). Cell-cycle inhibitors: three families united by a common cause. Gene 247: 1-15.

WAN, J. and GOLDMAN, D. (2016). Retina regeneration in zebrafish. Curr Opin Genet Dev 40: 41-47.

WEI, W., AYAD, N.G., WAN, Y., ZHANG, G.J., KIRSCHNER, M.W. and KAELIN, W.G., JR. (2004). Degradation of the SCF component Skp2 in cell-cycle phase G1 by the anaphase-promoting complex. Nature 428: 194-198.

WELCKER, M. and CLURMAN, B.E. (2008). FBW7 ubiquitin ligase: a tumour suppressor at the crossroads of cell division, growth and differentiation. Nat Rev Cancer 8: 83-93.

WILLEMS, A.R., SCHWAB, M. and TYERS, M. (2004). A hitchhiker's guide to the cullin ubiquitin ligases: SCF and its kin. Biochim Biophys Acta 1695: 133-170

WIRT, S.E., ADLER, A.S., GEBALA, V., WEIMANN, J.M., SCHAFFER, B.E., SADDIC L.A., VIATOUR, P., VOGEL, H., CHANG, H.Y., MEISSNER, A. et al., (2010). G1 arrest and differentiation can occur independently of $\mathrm{Rb}$ family function. $J$ Cell Biol 191: 809-825.

YAN, Y., FRISEN, J., LEE, M.H., MASSAGUE, J. and BARBACID, M. (1997). Ablation of the CDK inhibitor p57Kip2 results in increased apoptosis and delayed differentiation during mouse development. Genes Dev 11: 973-983.

YAO, G., LEE, T.J., MORI, S., NEVINS, J.R. and YOU, L. (2008). A bistable Rb-E2F switch underlies the restriction point. Nat Cell Biol 10: 476-482.

YEH, N., MILLER, J.P., GAUR, T., CAPELLINI, T.D., NIKOLICH-ZUGICH, J., DE LA HOZ, C., SELLERI, L., BROMAGE, T.G., VAN WIJNEN, A.J., STEIN, G.S. et al., (2007). Cooperation between p27 and p107 during endochondral ossification suggests a genetic pathway controlled by p27 and p130. Mol Cell Biol27: 5161-5171.

ZAMBON, A.C. (2010). Use of the Ki67 promoter to label cell cycle entry in living cells. Cytometry A 77: 564-570.

ZANET, J., FREIJE, A., RUIZ, M., COULON, V., SANZ, J.R., CHIESA, J. and GANDARILLAS, A. (2010). A mitosis block links active cell cycle with human epidermal differentiation and results in endoreplication. PLoS One 5: e15701.

ZHANG, P., LIEGEOIS, N.J., WONG, C., FINEGOLD, M., HOU, H., THOMPSON, J.C., SILVERMAN, A., HARPER, J.W., DEPINHO, R.A. and ELLEDGE, S.J. (1997). Altered cell differentiation and proliferation in mice lacking p57KIP2 indicates a role in Beckwith-Wiedemann syndrome. Nature 387: 151-158.

ZHANG, T. (2013). Phase portraits of the proliferation-quiescence decision. Sci Signal 6: pe37.

ZINDY, F., CUNNINGHAM, J.J., SHERR, C.J., JOGAL, S., SMEYNE, R.J. and ROUS SEL, M.F. (1999). Postnatal neuronal proliferation in mice lacking Ink4d and Kip1 inhibitors of cyclin-dependent kinases. Proc Natl Acad Sci USA 96: 13462-13467. 


\section{Further Related Reading, published previously in the Int. J. Dev. Biol.}

Changes in the expression of cyclin dependent kinase inhibitors during differentiation of immortalized fibroblasts into adipocytes Ibon Alonso, Antonio Baroja, Blanca Fernández, Raquel Vielba, Jon Elorriaga, Jairo Pérez-Sanz, Juan Aréchaga, Juan J. Goiriena de Gandarias and Carmen de la $\mathrm{Hoz}$

Int. J. Dev. Biol. (2017) 61: 89-93

https://doi.org/10.1387/ijdb.160416cd

Flexibility vs. robustness in cell cycle regulation of timing of M-phase entry in Xenopus laevis embryo cell-free extract

Mateusz Debowski, Mohammed El Dika, Jacek Malejczyk, Robert Zdanowski, Claude Prigent, Jean-Pierre Tassan, Malgorzata Kloc, Miroslaw Lachowicz and Jacek Z. Kubiak

Int. J. Dev. Biol. (2016) 60: 305-314

https://doi.org/10.1387/ijdb.160134jk

Chaperone-mediated chromatin assembly and transcriptional regulation in Xenopus laevis

Takashi Onikubo and David Shechter

Int. J. Dev. Biol. (2016) 60: 271-276

https://doi.org/10.1387/ijdb.130188ds

Aurora-A: an expedition to the pole of the spindle in Xenopus egg extracts Jacek Z. Kubiak and Claude Prigent

Int. J. Dev. Biol. (2016) 60: 255-261

https://doi.org/10.1387/ijdb.160189jk

The master Greatwall kinase, a critical regulator of mitosis and meiosis

Suzanne Vigneron, Perle Robert, Khaled Hached, Lena Sundermann, Sophie Charrasse, Jean-Claude Labbé, Anna Castro and Thierry Lorca

Int. J. Dev. Biol. (2016) 60: 245-254

https://doi.org/10.1387/ijdb.160155t|

Xenopus cell-free extracts and their contribution to the study of DNA replication and other complex biological processes

J. Julian Blow and Ronald A. Laskey

Int. J. Dev. Biol. (2016) 60: 201-207

https://doi.org/10.1387/ijdb.160142jb

Reprogramming of somatic cells and nuclei by Xenopus oocyte and egg extracts Alexander A. Tokmakov, Tetsushi Iwasaki, Ken-Ichi Sato and Shinji Kamada Int. J. Dev. Biol. (2016) 60: 289-296

https://doi.org/10.1387/ijdb.160163at

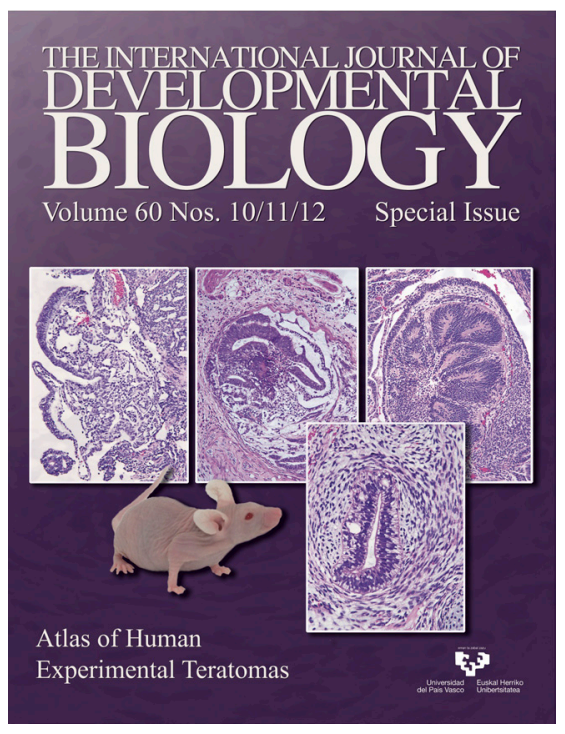

5 yr ISI Impact Factor $(2013)=2.879$

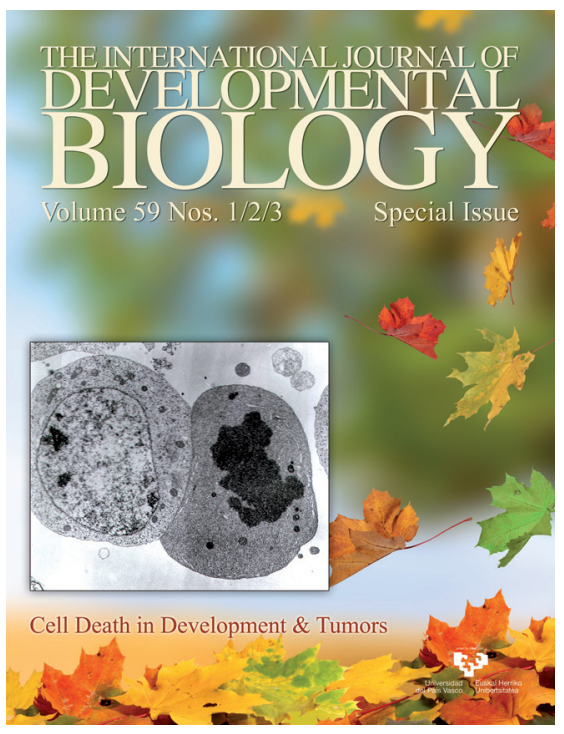

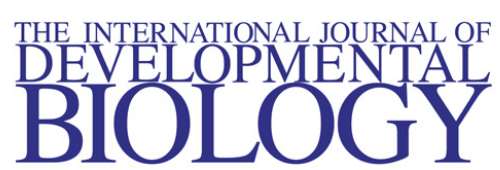

Volume 48 Nos. 5/6

Special issue

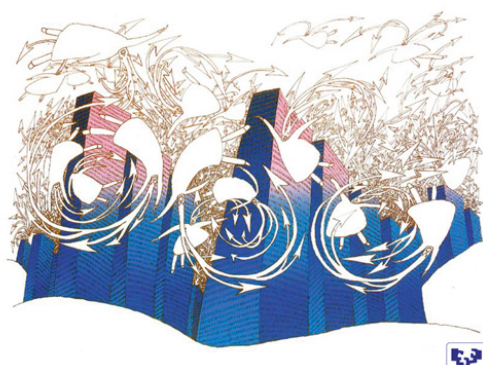

Invasion in cancer and embryonic development

Sicher

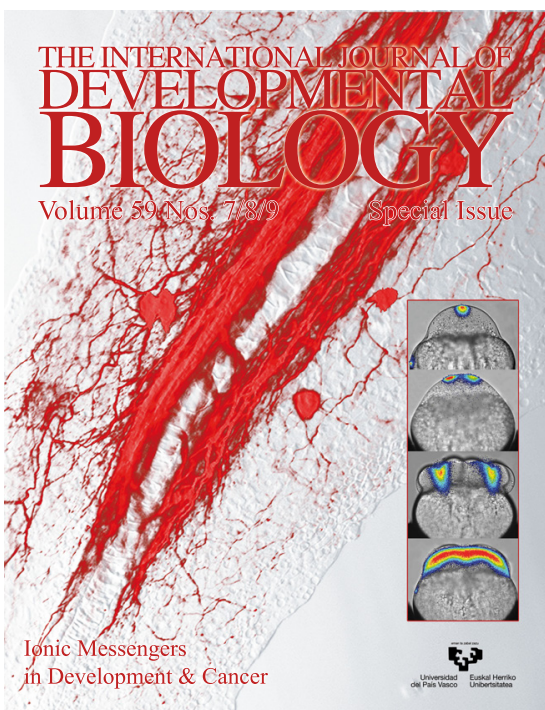

